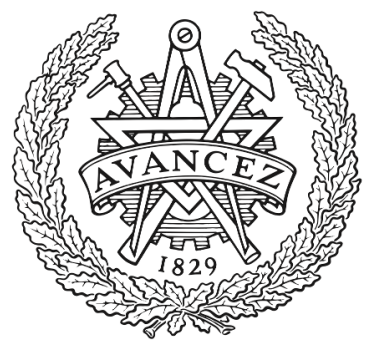

CHALMERS

UNIVERSITY OF TECHNOLOGY

\title{
Economic and greenhouse gas emissions assessment of excess biomass extracted from future kraft pulp mills
}

Downloaded from: https://research.chalmers.se, 2023-04-26 09:28 UTC

Citation for the original published paper (version of record):

Ådahl, A., Harvey, S., Berntsson, T. (2002). Economic and greenhouse gas emissions assessment of excess biomass extracted from future kraft

pulp mills. Proceedings of the 6th International Conference on Greenhouse Gas Control

Technologies, 1: 1237-1242

N.B. When citing this work, cite the original published paper. 


\title{
ECONOMIC AND GREENHOUSE GAS EMISSIONS ASSESSMENT OF EXCESS BIOMASS EXTRACTED FROM FUTURE KRAFT PULP MILLS
}

\author{
A. Ådahl, S. Harvey and T. Berntsson \\ Department of Heat and Power Technology, Chalmers University of Technology, \\ 41296 Göteborg, Sweden.
}

\begin{abstract}
Different studies have shown that the process heat requirements of future pulp mills can be satisfied using available internal biomass (bark and lignin), which are process by-products. Assuming that biomass is $\mathrm{CO}_{2}$ neutral, further reducing the process heat demand will not therefore lead to further reduction of Greenhouse Gas (GHG) emissions - unless the excess biomass is extracted and used elsewhere to substitute fossil fuels. Previous work has demonstrated the potential to extract and export significant amounts of biofuel from future pulp mills. The associated extraction costs can be competitive with conventional forest fuels. However, biofuel extraction reduces the mill's potential to cogenerate electric power. This reduced power output must be compensated by increased purchased power from the grid, with associated costs and emissions. Such emissions must be affected to the extracted biofuel, which cannot therefore be considered as $\mathrm{CO}_{2}$ neutral. This paper presents results for costs and associated greenhouse gas emissions for excess biofuel extracted from a pulp mill. The results show that the extraction costs are competitive, but that the greenhouse gas emissions associated with the exported biofuel can be significant and must therefore not be neglected.
\end{abstract}

\section{INTRODUCTION}

Biofuel prices have begun to increase in Sweden [1], as a result of increased demand resulting from energy and environmental policy instruments [2]. Similarly, EU policy [3] aims at increasing usage of biomass as a renewable fuel. To develop future sustainable energy systems with low greenhouse gas (GHG) emissions, it is necessary to not only increase use of biofuels, but also to use such fuels as efficiently as possible.

Swedish kraft pulp mills currently use oil and internal biofuels to satisfy process heat demands. The Swedish "EcoCyclic Pulp Mill" project has defined the energy system for a reference mill incorporating best available technology [4]. According to this project, future pulp mills should not only be energy selfsufficient using internal biofuel resources, but should also be able to export excess bark and lignin $[5,6]$. Internal biofuels are pulp process by-products, and the total production costs for biofuel extraction can be computed based on costs for process integration measures to reduce the mill heat demand (and thereby the process biofuel consumption), biofuel processing costs, and changes in electric power costs since decreasing the mill steam demand decreases the amount of electric power that can be cogenerated. Furthermore, biofuels are generally assumed to be $\mathrm{CO}_{2}$ neutral ${ }^{1}$ due to the closed carbon cycle. However, given the above

\footnotetext{
${ }^{1}$ Other sources of GHG emissions associated with biofuel usage include for example harvesting and transportation. Land use practises can also impact net GHG emissions for biofuels. These aspects are not further considered in this study, since these emissions are assumed to be charged to the pulping process.
} 
mentioned changes to the mill steam and power balances resulting from biofuel extraction, the exported biofuel should not be considered as $\mathrm{CO}_{2}$ neutral, but should rather be charged with the emissions associated with the extraction process.

The aim of this paper is to assess costs and global GHG emissions associated with biofuel extracted from a future pulp mill. The paper presents a case study based upon a Swedish kraft pulp mill.

Identifying potential energy efficiency measures for retrofitting of a pulp plant requires the use of appropriate tools. The measures considered in this paper were identified in previous work at the authors' department using process integration tools, including both traditional pinch technology tools [7,8] and advanced tools specially suited to retrofit situations $[9,10]$. A description of appropriate tools for systematic analysis of GHG emissions associated with process integration measures may be found in [11] and [12].

\section{CASE STUDY PULP MILL PLANT CHARACTERISTICS}

The pulp mill studied in this paper is a Swedish combined pulp and board mill producing 530,000 tonnes/year of board based on both CTMP and sulphate pulp. The current mill heat demand is 195 MW. Electricity is cogenerated for on-site use. Additional power is purchased from the grid.

Effluents from part of the plant are currently discharged to an aerated pond. New environmental restrictions require that the load on the pond be decreased. In order to treat the effluent stream its concentration must first be increased in a pre-evaporator. Conventional pre-evaporation increases the mill steam consumption. Alternatively, process excess heat identified by pinch technology could be used as a heat source. In previous work at the authors' department [13], excess heat suitable for effluent pre-evaporation has been identified at three temperature levels. The excess heat could also be used as heat source to generate additional steam by heat pumping, thus reducing the boiler fuel consumption. Three alternative process integration measures were therefore investigated for decreasing boiler steam consumption to drive the pre-evaporation process, namely:

(I) heat pumping of low temperature mill excess heat;

(II) recovery of mill excess heat;

(III) use of recovered mill excess heat in combination with heat pumping.

Based on available process stream data and heat pump characteristics, the potential for delivered heat from the heat pump was estimated to be $5 \mathrm{MW}$, using a conventional mechanical vapour recompression (MVR) heat pump. The three alternative solutions are analysed with the conventional steam solution as baseline (reference). Table 1 summarises the key data for the analysis. The reference situation requires an increase of biofuel consumption in order to meet the increased steam demand of 18.6 MW. Alternative III decreases the plant's steam demand by 22.1 MW compared to the reference, i.e. not only the pre-evaporator unit can be run using waste heat only, but steam from the MVR heat pump can be used to reduce the boiler steam demand for other parts of the mill. The potential for biofuel export from the mill was estimated based on the following assumptions:

- Oil is not used as a fuel at the mill, i.e. a reduction of steam demand (compared to the reference) leads to a corresponding potential for biofuel export, adjusted for conversion efficiencies;

- Extracted biofuel may be in the form of bark or lignin. Energy requirements and emissions associated with further processing and transporting of the extracted biofuel are not considered;

- The biofuel boiler efficiency is set at 0.85 , based on the fuel lower heating value;

- The changes in cogenerated electric power associated with changes in mill steam demand are estimated based on the mill's steam turbine operating curves [14].

- The mill operates $8760 \mathrm{hrs} /$ year, including the cogeneration unit. Although current electricity prices in Scandinavia do not justify year round cogeneration, a number of studies (e.g. [15]) indicate a clear need for increased base-load (year-round) power generation in the near future. 
TABLE 1

DATA FOR RETROFIT ALTERNATIVES

\begin{tabular}{|c|c|c|c|c|c|c||c|c|}
\cline { 3 - 8 } \multicolumn{2}{c|}{} & \multicolumn{2}{c|}{ Process data } & \multicolumn{2}{c||}{ Investment data } & \multicolumn{2}{c|}{ Results } \\
\hline & $\begin{array}{c}\text { Retrofit Measures } \\
\text { Pre-evaporator heat } \\
\text { source (BS=Boiler Steam) }\end{array}$ & $\begin{array}{c}\text { Number of pre- } \\
\text { evaporator } \\
\text { units }\end{array}$ & $\begin{array}{c}\text { Decreased } \\
\text { steam demand } \\
\text { w.r.t. reference } \\
\text { [MW] }\end{array}$ & $\begin{array}{c}\text { Pre- } \\
\text { evaporator } \\
\text { [MSEK] }\end{array}$ & $\begin{array}{c}\text { Heat } \\
\text { pump } \\
\text { [MSEK] }\end{array}$ & $\begin{array}{c}\text { Rearrange- } \\
\text { ments for } \\
\text { heat pump } \\
{[\mathrm{MSEK}]}\end{array}$ & $\begin{array}{c}\text { Extracted } \\
\text { biofuel } \\
\text { [GWh/year] }\end{array}$ & $\begin{array}{c}\text { Increased } \\
\text { power from } \\
\text { grid } \\
{[\mathrm{GWh} / \text { year] }}\end{array}$ \\
\hline Ref & Boiler steam only & 4 & & & & & \\
\hline I & $\begin{array}{c}\text { BS + Heat pumping of } \\
\text { excess heat }\end{array}$ & 4 & 5.0 & 76.6 & 5.52 & 4.6 & 64 & 0 \\
\hline II & BS + Excess heat & 9 & 17.1 & 110 & 0 & 0 & 221 & 38.7 \\
\hline III & $\begin{array}{c}\text { Excess heat and heat } \\
\text { pumping }\end{array}$ & 9 & 22.1 & 110 & 5.52 & 4.6 & 286 & 54.6 \\
\hline
\end{tabular}

\section{ASSESSMENT OF EXTRACTION COSTS AND ASSOCIATED GHG EMISSIONS}

Three alternative energy saving measures are investigated for the pulp mill, as discussed in the previous section. The baseline chosen is conventional live steam pre-evaporation for the pulp mill. The biofuel released from the pulp mill is considered as a by-product of the pulping process, i.e. LCA GHG emission values associated with biomass harvesting and transportation together with biomass raw material costs are allocated to the pulping process and not to the by-products. Biofuel extraction costs are therefore constituted by investment costs to reduce the boiler steam demand (see Table 1) plus increased grid power purchase costs due to the decreased potential for mill-site cogeneration (Table 1 presents the estimated increase in power purchases from the grid). Extracted biofuel processing costs (e.g. drying and pelletising) are not considered in this study. Capital costs are annualised using the annuity method with a capital recovery factor of 0.2 (except for the heat pump where 0.42 is used, reflecting the demand for a shorter payback period for this type of equipment).

As discussed previously, the different measures considered affect the pulp mill electric power balance, and additional power must be purchased from the grid (see Table 1). The GHG emissions associated with the additional power generated by the grid must be allocated to the extracted biofuel. Three levels of electricity grid emissions are considered (Table 2), reflecting uncertainty about the evolution of the power system mix of technologies, and about the corresponding choice of baseline for calculations. Two levels of electricity prices are considered. The low value reflects the current situation in Scandinavia, with low power prices due to market deregulation and relative abundance of low-cost generation capacity. The higher value reflects a future situation where it is assumed that the power price is set by the generation costs of new natural gas fired combined cycle plants (NGCC).

TABLE 2

ELECTRICITY GRID SCENARIOS

\begin{tabular}{|c|c|c|}
\hline $\begin{array}{c}\text { Electricity price on the } \\
\text { Nordic power market } \\
(\mathrm{SEK} / \mathrm{MWh})\end{array}$ & $\begin{array}{c}\text { Electricity grid GHG } \\
\text { emissions }\left(\mathrm{kg} / \mathrm{MWh}_{\mathrm{el}}\right)\end{array}$ & $\begin{array}{c}\text { Corresponding electricity production in the future deregulated } \\
\text { Northern European electricity market }\end{array}$ \\
\hline 150 & 110 & $\begin{array}{c}\text { Average Nordic power system based on hydropower, nuclear } \\
\text { power and fossil fuel power plants }\end{array}$ \\
\hline 300 & 380 & $\begin{array}{c}\text { Natural gas combined cycle (NGCC) power generation as } \\
\text { marginal production technology }\end{array}$ \\
\cline { 1 - 1 } 300 & 890 & $\begin{array}{c}\text { Coal-fired steam turbine power plants as marginal production } \\
\text { technology }\end{array}$ \\
\hline 150 & \multirow{2}{*}{300} &
\end{tabular}




\section{RESULTS}

Figure 2 shows the results for biofuel specific extraction costs resulting from the considered pulp preevaporation plant retrofit measures. For comparisons, the figure also shows the current Swedish market price for bark and other wood-waste fuels taken from [1]. The market price for premium forest fuels is higher, but in this study it is assumed that the biofuel extracted is bark or lignin. Due to uncertainty regarding the attractiveness of lignin on the biofuel market, it is assumed in the study that this type of fuel has the same market value as bark. In order to motivate such an investment, the biofuel extraction costs must clearly be lower than the market value for the extracted biofuel. As shown in the figure, the specific extraction costs vary for the different pulp mill measures considered. The market electricity price also has a significant impact on the extraction costs. Regardless of the electricity price, the extraction costs associated with Measure I is higher than the market value of the biofuel. For the lower electricity price, Measures II and III are competitive, whereas for the higher electricity price, only Measure II is competitive. The figure also shows that if biofuel market prices increase in the future, all three measures are likely to be competitive, even with future high electricity prices.

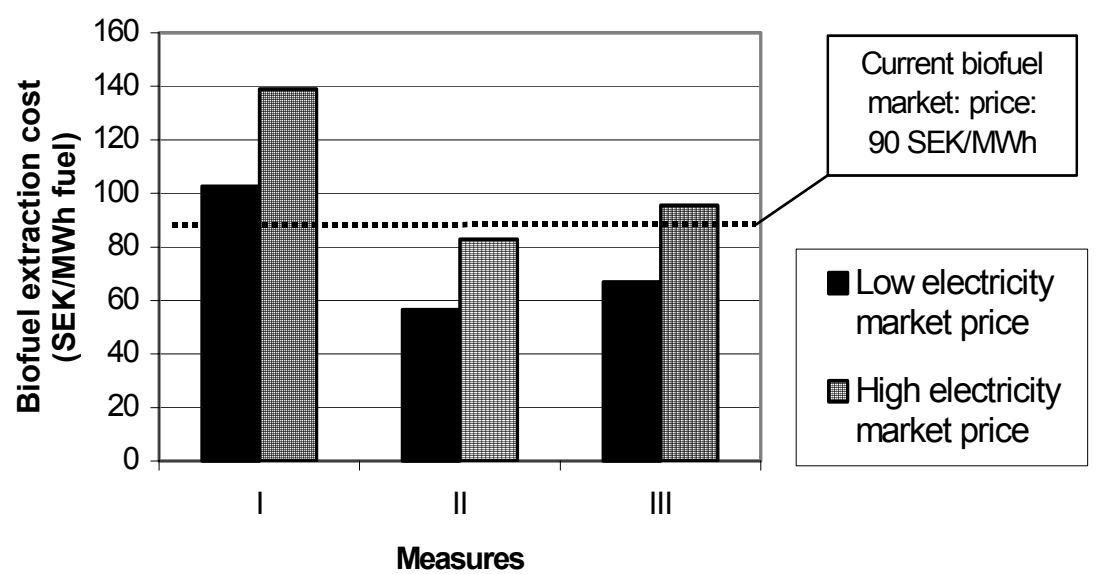

Figure 2: Biofuel specific extraction costs associated with process integration measures at the pulp mill (Note: extraction costs include annualised investment costs plus electricity costs due to changes to the site power balance)

It should also be noted that Figure 2 presents specific biofuel extraction costs. The total investment depends on the amount extracted (see Table 1). Measure I corresponds to a relatively low biofuel extraction potential (64 GWh/yr.) at a relatively high specific extraction costs. Measures II and III correspond to a significantly higher extraction potential (221 resp. $286 \mathrm{GWh} / \mathrm{yr}$.) at significantly lower specific extraction costs.

Figure 3 presents results for global $\mathrm{CO}_{2}$ emissions increase for all retrofit measures, compared to the reference boiler steam driven pre-evaporators. The results are presented as specific emissions per unit extracted biofuel. The key values from Figures 2 and 3 are presented in Table 3. Three levels of emissions associated with grid electric power generation are considered (see Table 2) for assessing the impact on global GHG emissions associated with changes to the pulp mill net power balance. For comparison purposes, the figure includes reference values typically used in LCA assessment studies for GHG emissions for three types of fuels, namely oil, natural gas and virgin forest fuel. The results presented in Figure 2 showed that electric power prices have a significant impact on specific extraction costs. Figure 3 shows that the impact of grid emissions is even more significant. From a GHG emissions perspective, extracted biofuel is only comparable to virgin forest biofuel only when grid emissions are low. If grid emissions are high, the GHG emissions associated with the released biofuel are somewhat lower than natural gas GHG emissions, but clearly much higher than for virgin forest biofuels. 


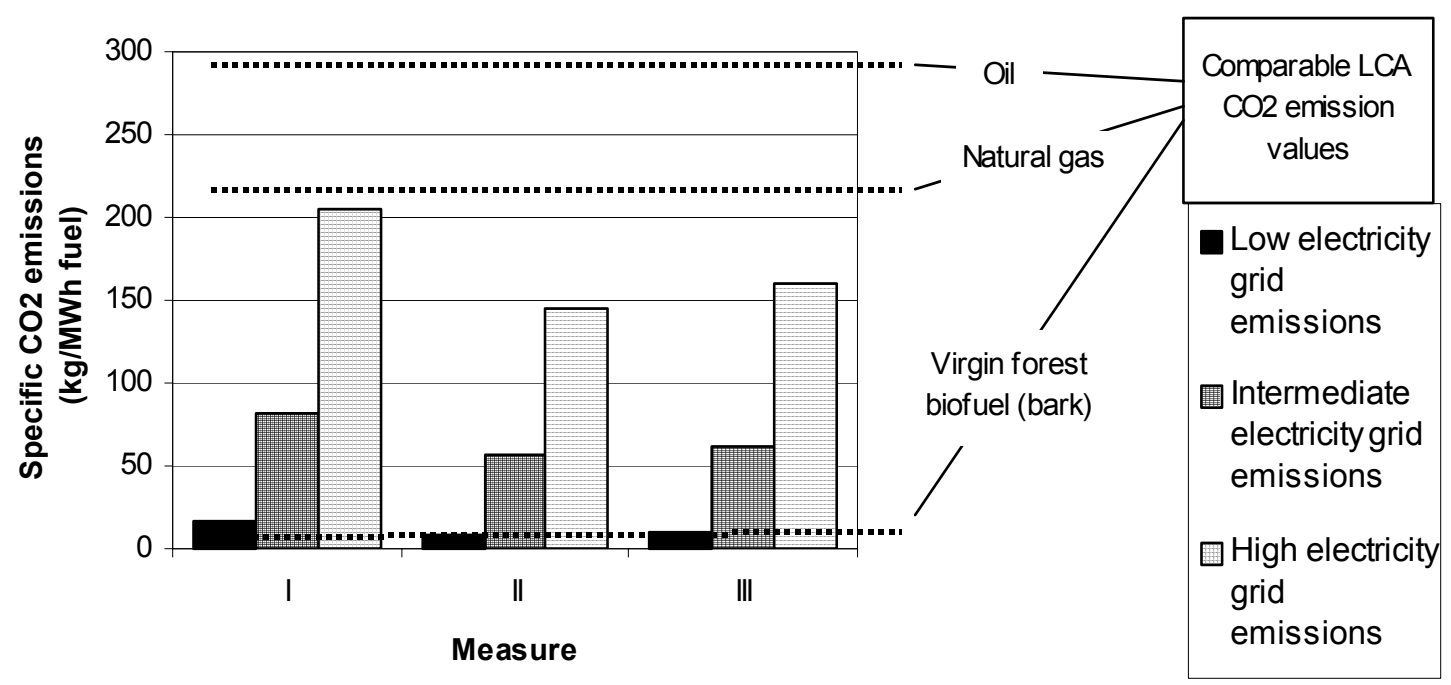

Figure 3: Global $\mathrm{CO}_{2}$ emissions associated with extracted biofuel

TABLE 3

SUMMARY OF BIOFUEL EXTRACTION COSTS AND SPECIFIC $\mathrm{CO}_{2}$ EMISSIONS

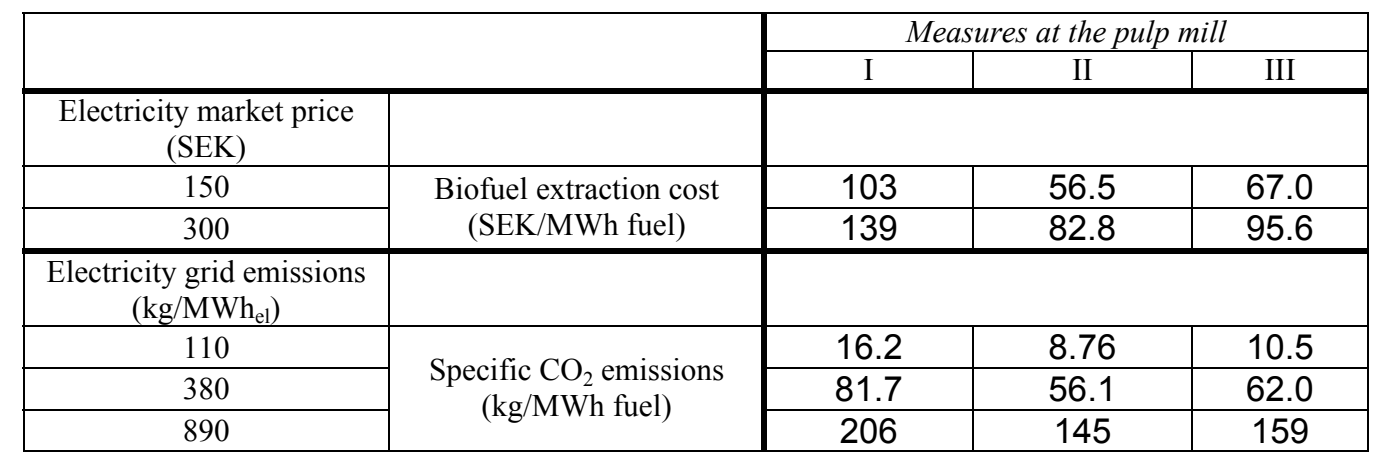

\section{DISCUSSION}

As pulp mills become more energy efficient, there is an increasing potential export of excess biofuel from this industry. The goal of this paper was to investigate costs and associated GHG emissions for extracted excess biofuel, based on results from a case study that investigated technical and economic opportunities for excess heat utilisation in a Swedish pulp and board mill. The study accounts for costs and emissions resulting from changes in the mill's electric power balance.

The results show that for the case study considered, excess biofuel can be extracted at costs that are often competitive compared with the market value of the extracted fuel. The extraction costs are significantly higher when the economic value of the loss of cogenerated power is high. As the demand for biofuels increases in the future, there is therefore a clear incentive to further investigate extraction of excess biofuel from pulp mills. This may be seen as a business opportunity by the industry itself, or alternatively it may be seen as an opportunity for external investors wishing to invest in a secure source of low-cost biofuel. Jointventure strategies involving both mills and external market actors may also be attractive. International investors may become interested in the Swedish pulp mill biofuel surplus potential, under the terms of the joint implementation mechanism provided for in the Kyoto protocol. Swedish biofuel could thereby be used for e.g. fossil fuel substitution in biofuel-deficient areas of Europe.

This study however shows that, unlike virgin forest biofuels, extracted biofuels can have relatively high associated emissions (in certain cases close to the emissions levels of natural gas), depending on the reference grid emissions associated with electric power generation. In order to achieve global greenhouse 
gas reductions, biofuel must clearly be used for substitution of fossil fuels. Furthermore, given the GHG emissions associated with excess biofuels extracted from pulp mills, these fuels must be used to be used to increase usage of biofuels, and should not compete with virgin forest biofuels, as discussed in [16].

In order to assess the cost-effectiveness of extracting excess biofuel from pulp mills as a means to reduce global greenhouse gas emissions, it is clearly important to include the final usage of the extracted biofuel in the analysis. Furthermore, the results of this study show that the specific extraction costs are dependent on both the nature of the energy-efficiency measures implemented in order to release the excess biofuel, and on the economic value of the cogenerated electric power. Thus, the cost-effectiveness of greenhouse gas emissions reduction based on extraction of excess biofuel from pulp mills and usage of this biofuel to substitute fossil fuels requires a detailed analysis adopting a suitable system perspective so as to account for all major effects. Results from this type of study must be used as input for such an analysis.

\section{REFERENCES}

1. The Swedish Energy Agency. (2002). Prisblad för biobränslen, torv mm. Nr 2/2002, www.stem.se.

2. The Swedish Government. (2002). Energipropositionen 2002, www.regeringen.se.

3. The EU Commission of the European Communities, Commission Staff Working Paper (2001). Third Communication from the European Community under the UN Framework Convention on Climate Change, www.europa.eu.int.

4. $\quad$ STFI. (2000). Final report KAM 1, 1996-1999, Report A32. STFI, Stockholm, Sweden.

5. Wising, U. (2001). Licentiate Thesis, Chalmers University of Technology, Sweden.

6. Algehed, J. (2002). PhD Thesis, Chalmers University of Technology, Sweden.

7. Linnhoff, B et al. (1994). User's Guide on Process Integration for the Efficient Use of Energy. IChemE, Rugby, UK.

8. $\quad$ Linnhoff, B. (1994). Chem. Eng. Progress, Vol. 90, No. 8, 32-57.

9. Carlsson, A., Franck, P.-Å., and Berntsson, T. (1993). Chemical Eng. Progr. Vol 89 (3), pp 87-96.

10. Nordman, R., and Berntsson, T. (2001). Canadian Jnl of Chem. Eng. Vol 79 (4), pp 655-662.

11. Axelsson, H., Åsblad, A., and, Berntsson, T. (1999). Applied Thermal Eng., Vol. 17, 993-1003.

12. Ådahl A., Harvey S. and, Berntsson T. (2000). ECOS 2000 proceedings, Eurotherm Seminar 65. 2000;(3): 1213-1224.

13. Bengtsson, C., Nordman, R. and, Berntsson, T. (2002). Applied Thermal Eng., Vol. 22, 1069-1081.

14. Bengtsson, C., and Karlsson, M. (1999). Co-operation of the MIND-method and the Pinch Technology - energy efficient pre-evaporation of bleach plant filtrate using waste heat. Report $\mathrm{nr} 4$, ISSN 1403-8307, Program Energisystem, Linköping University, Sweden.

15. Energimyndigheten. (2001). Läget på den Nordeuropeiska elmarknaden - ett försök till en problemorienterad analys. Report nr ER23:2001 ISSN 1403-1892, Eskilstuna, Sweden.

16. Energimydnigheten. (2001). Underlag för målformulering för Långsiktiga avtal med energiintensiv industri. App. 3 in Näringsdepartementet report Ds 2001:65, Fritzes, Stockholm. 